\title{
A CASE STUDY ON SOLID WASTE MANAGEMENT IN YAVATMAL CITY
}

\author{
ABHAYCHANDEKAR ${ }^{1} \&$ ROSHAN UMATE ${ }^{2}$ \\ ${ }^{I}$ Mechanical Engineering / Ms. P.S. Chakole, YCCE, Nagpur, India
}

${ }^{2}$ Research Scientist, Jawaharlal Nehru Medical College, Datta Meghe Institute of Medical Sciences, Sawangi, Wardha, India

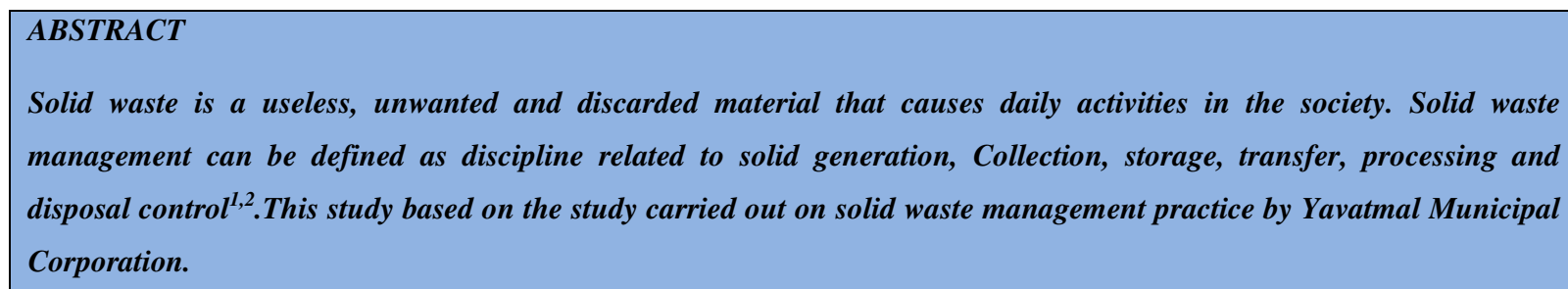

KEYWORDS: Solid Waste, Solid Generation \& Discarded Material

Received: Jun 09, 2020; Accepted: Jun 29, 2020; Published: Aug 11, 2020; Paper Id.: IJMPERDJUN2020716

\section{INTRODUCTION}

\section{Case Description}

Yavatmal is a city and municipal council in the Indianstate of Maharashtra. It is the administrative headquarters of Yavatmal District. Yavatmal is around $90 \mathrm{~km}$ away from divisional headquarters Amravati while it is $670 \mathrm{~km}$ (420 mi) away from the state capital Mumbai. Yavatmal located at $20^{\circ} 24^{\prime} 00^{\prime \prime}$ North latitude, $78^{\circ} 07^{\prime} 59^{\prime \prime}$ East longitudes. Elevation above sea level is $451 \mathrm{~m}$ (1479 ft.). Area of Yavatmal city is $100 \mathrm{~km} 2$ (40 sq mi), population of city is 138,551 , and Density is $1,400 / \mathrm{km} 2(3,600 / \mathrm{sq} \mathrm{mi}$.

The total solid waste production in Yavatmal city is 24 tons per day and 36 to 40 metric tons of waste. Approximately $200 \mathrm{gm} / \mathrm{capita/day.} \mathrm{From} \mathrm{that} \mathrm{solid} \mathrm{waste.}$

Municipal solid waste management activities, from generation to final disposal can be divided into six functional components ${ }^{3}$. They are-

- Waste generation

- Storage

- Collection

- Transportation

- Segregation \& Processing

- Disposal

\section{Collection of Solid Waste}

Flow chart showing collection of solid waste in as below 


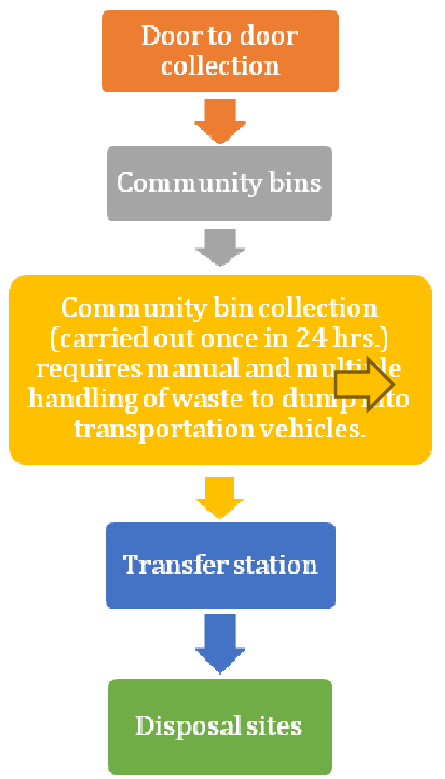

Figure 1

The city are divided into the following five sections for solid waste collection as part of decentralization

- Arninaka square

- $\quad$ Bus stop

- Girls hostel, Near postal ground

- Market Area

- Sanjay Gandhi School

There are many types of municipal solid waste Such as food waste, commercial waste, organizational waste, sweeping, industrial waste, construction waste and sanitation waste. These include recyclables (paper, plastics, glass and metals, etc.), toxic substances (paints, pesticides, used batteries, medicine, etc.), compostable organic matter (fruit and vegetable peels, food waste), solid waste (sanitary napkins, etc. $)^{4,5,6}$.

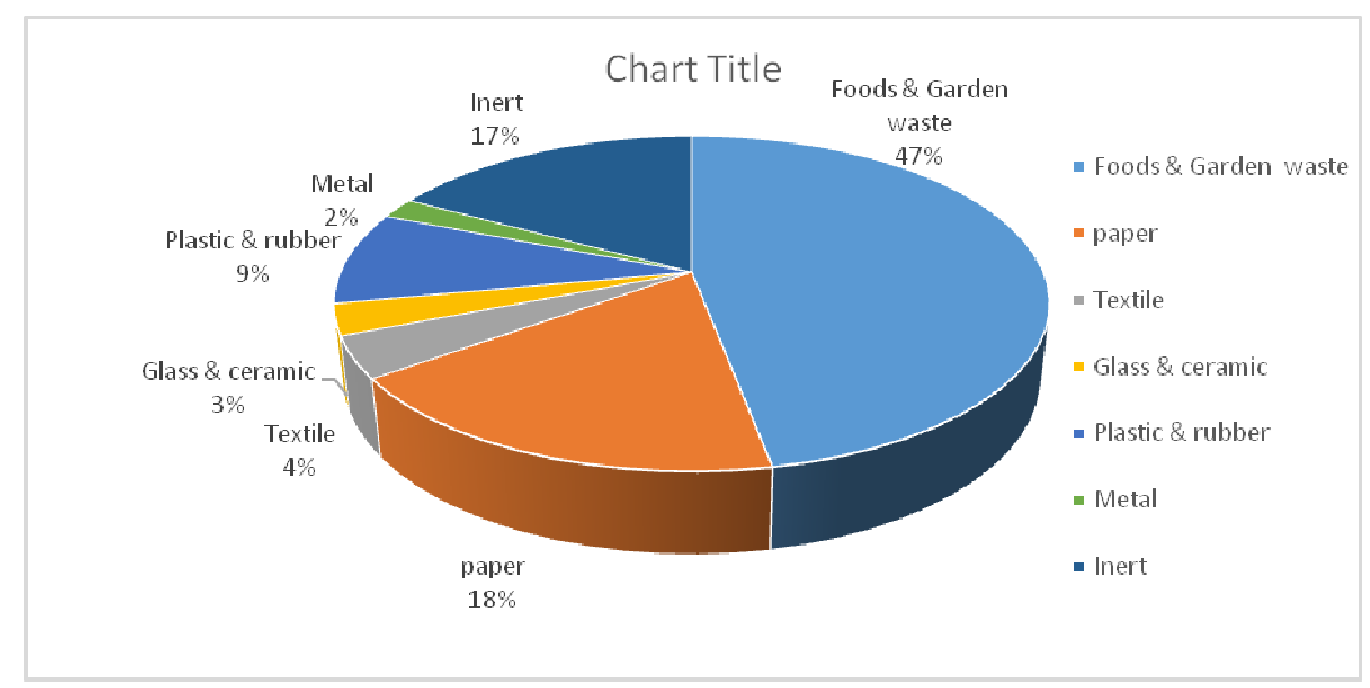

Figure 2: Composition of Municipal Solid Waste in a Typical Yavatmal City. 


\section{Disposal of Solid Waste}

Savargad, a village located at a distance of $8 \mathrm{~km}$ from Yavatmal city, has a site for municipal solid waste management.

Disposal of solid waste is done by the following two methods: ${ }^{7,8,9}$

- Composting: -This is done by vermilion composting of any type of bio-enhanced waste like biodegradable parts of hotels, shelters, commercial markets, vegetable waste, leaf waste etc. The size of each earthworm composting rack is $6.12 \mathrm{~m} \mathrm{x} 1.52 \mathrm{~m} \times 0.6 \mathrm{~m}$. Of steel. This takes a period of two months

- Land filling:-Waste is stored on the top of the hill in 5acres area. All in organic material is used for the land filling and dumping.

\section{CONCLUSIONS}

The data collected showed that the highest rate of rejection due to food and garden wastes, recycling of food and garden wastes was the second highest in paper and the third heaviest material. The percentage of plastic carry bags was higher, where glass, ceramics and metal were almost identical to each other.

Garbage dumps will be provided in public places and all sources will be compulsorily allocated. It would be desirable to set up transfer station to economize the expenditure on the transportation.

Manual Separation of Solid Waste Platform ${ }^{10,11,12}$ is one of the best way to recover and recycle materials like metal, plastic, glass and rubber as it is at the disposal site in Savargad village. This should be done throughout the year. The system should be based on environmental protection regulations (reduce, reuse, and recover) ${ }^{13,14,15,16}$.

Public awareness, political will and public participation are essential for the successful implementation of the legal provisions and to have an integrated approach towards sustainable management of municipal solidwastes.

\section{REFERENCES}

1. Gupta S, Mohan $K$ et al. Solid waste management in India: options and opportunities. Resources, Conservation and Recycling. 1998; 24(2): 137-154.

2. Narayana T. Municipal solid waste management in India: From waste disposal to recovery of resources? Waste Management. 2009; 29(3): 1163-1166.

3. Sharholya M, Ahmad K et al. Municipal solid waste management in Indian cities - A review. Waste Management. 2008; 28(2): 459-467.

4. Kavitha, S., and G. Manimekalai. "A study on waste disposal management in garment industry." International Journal of Textile and Fashion Technology (IJTFT) 4.5 (2014): 37-42.

5. Rajendra Kumar Kaushal et al.Municipal Solid Waste Management inIndia-Current State and FutureChallenges: A Review. International Journal of Engineering Science and Technology. 2012; 4(4): 1473- 1489.

6. Sharholy $M$, Ahmad $K$ et al. Municipal solid waste characteristics and management in Allahabad, India.Waste Management. 2007; 27(4): 490-496.

7. Idris A, Inane B et al. Overview of waste disposal and landfills/dumps in Asian countries. Material Cycles andWaste Management. 2004; 16: 104-110. 
8. Sarmah, P. U. R. B. A. S. H. R. E. E., et al. "Design, of a Combination of Compost Plant and Landfill for Municipal Solid Waste Management of Guahati City." International Journal of Civil, Structural, Environmental and Infrastructure Engineering Research and Development 5.4 (2015): 45-52.

9. Jha M., Sondhi $O$ et al. Solid waste management - a case study. Indian Journal of Environmental Protection.2003; 23(10): 1153-1160.

10. Sharholy M, Ahmad K et al. Analysis of municipal solid waste management systems in Delhi $-a$

11. Review. In Book of Proceedings for the second International Congress of Chemistry and Environment, Indore, India. 2005: 773-777.

12. Ahsan, N. Solid waste management plan for Indian megacities.Indian Journal of Environmental Protection. 1999; 19(2); 90-95.

13. Suganya, K., R. Velusamy, and S. Thiyageshwari. "Augmenting the Liquid Waste Management Skills of Rural Shg Women of Madurai District Through Eco-Wash Literacy." International Journal of Agricultural Science and Research (IJASR) 7.4 (2017): 359-362.

14. Kansal A. Solid waste management strategies for India. Indian Journal of Environmental Protection. 2002; 22(4): 444448.

15. Dayal G. Solid wastes: sources, implications and management. Indian Journal of Environmental Protection. 1994; 14 (9): $669-677$.

16. Khan M, Burney F. Forecasting solid waste composition - an important consideration in resource recovery and recycling. Resources Conservation and Recycling. 1989; 3:1-17.

17. Johny, Joice, et al. "Automatic Plastic Separating Technology For Solid Waste Disposal." Research and Development (IJCSEIERD) 3.2 (2013): 99-108.

18. Kumar S, Bhattacharyya $J$ et al. Assessment of the status of municipal solidwaste management in metro cities, state capitals, class I cities, and class II towns in India: an insight. Waste Management. 2009: 29:883-95.

19. Hazra T, Goel S. Solid waste management in Kolkata, India: Practices and challenges. Waste Management. 2009; 29(1): 470-478.

20. Rathi S. Alternative approaches for better municipal solid waste management in Mumbai, India. Waste Management. 2006; 26(10): 1192-1200. 